\title{
Surface sediment properties and heavy metal pollution assessment in the Pearl River Estuary, China
}

\author{
Guangming Zhao ${ }^{1,2,3} \cdot$ Siyuan Ye ${ }^{1,2} \cdot$ Hongming Yuan ${ }^{1} \cdot$ Xigui Ding $^{1} \cdot$ Jin Wang ${ }^{1}$
}

Received: 23 December 2015 / Accepted: 26 October 2016 / Published online: 14 November 2016

(C) The Author(s) 2016. This article is published with open access at Springerlink.com

\begin{abstract}
Grain size and concentrations of heavy metals (arsenic (As), cadmium $(\mathrm{Cd})$, chromium $(\mathrm{Cr})$, copper $(\mathrm{Cu})$, mercury $(\mathrm{Hg})$, lead $(\mathrm{Pb})$, and zinc $(\mathrm{Zn}))$ of 148 surface sediments and activities of ${ }^{210} \mathrm{~Pb}$ and heavy metal concetrantions of one sediment core from the Pearl River Estuary were analyzed. The surface sediments were dominated by silt and sandy silt. Sediment type controlled the spatial distribution patterns of the heavy metals. The heavy metal concentrations in the sediments ranged from 3.34 to $37.11 \mathrm{mg} / \mathrm{kg}$ for As, 0.06 to $2.06 \mathrm{mg} / \mathrm{kg}$ for $\mathrm{Cd}, 12$ to $130 \mathrm{mg} / \mathrm{kg}$ for $\mathrm{Cr}, 5.8$ to $170.6 \mathrm{mg} / \mathrm{kg}$ for $\mathrm{Cu}, 0.01$ to $0.25 \mathrm{mg} / \mathrm{kg}$ for $\mathrm{Hg}, 23$ to $78 \mathrm{mg} / \mathrm{kg}$ for Pb, and 32 to $259 \mathrm{mg} / \mathrm{kg}$ for $\mathrm{Zn}$. Both contents of clay and organic carbons were significantly positively correlated with heavy metals. The baseline values of elements in the study area were $12.97 \mathrm{mg} / \mathrm{kg}$ for As, $0.14 \mathrm{mg} / \mathrm{kg}$ for Cd, $68 \mathrm{mg} / \mathrm{kg}$ for $\mathrm{Cr}, 28.9 \mathrm{mg} / \mathrm{kg}$ for $\mathrm{Cu}, 0.08 \mathrm{mg} / \mathrm{kg}$ for $\mathrm{Hg}$, $33 \mathrm{mg} / \mathrm{kg}$ for $\mathrm{Pb}$, and $92 \mathrm{mg} / \mathrm{kg}$ for $\mathrm{Zn}$. The metal enrichment factor (EF) and geoaccumulation index (Igeo) were calculated to assess anthropogenic contamination. Results showed slight to moderate $\mathrm{Cd}$ contamination in the region. Principle component analysis indicated that $\mathrm{Cd}$ could be attributed to anthropogenic sources; As and $\mathrm{Hg}$ were predominantly affected by
\end{abstract}

Responsible editor: Philippe Garrigues

Siyuan Ye

siyuanye@hotmail.com

1 Key Laboratory of Coastal Wetlands Biogeosciences, China Geologic Survey, Qingdao 266071, People's Republic of China

2 Laboratory for Marine Geology, Qingdao National Laboratory for Marine Science and Technology, Qingdao 266061, People's Republic of China

3 College of Marine Geo-science, Ocean University of China, Qingdao 266100, People's Republic of China human activities; and $\mathrm{Pb}, \mathrm{Cr}, \mathrm{Cu}$, and $\mathrm{Zn}$ were associated with both natural and anthropogenic sources.

Keywords Sediment properties · Heavy metals · Pollution assessment · Pearl River Estuary

\section{Introduction}

Heavy metals are of considerable environmental concern due to their toxicity, multiple sources, nonbiodegradable properties, and accumulative behaviors. Estuaries, which are regions of active land-ocean interaction, respond sensitively to natural processes and anthropogenic activities (Li et al. 2007). Estuarine sediments are recognized as an important sink for heavy metals and other contaminants (Ip et al. 2004) and have attracted much attention (Hu et al. 2013a; Venkatramanan et al. 2015; Wang et al. 2015; Wang et al. 2014b; Woods et al. 2012; Xu et al. 2014; Yang et al. 2015; Zhang et al. 2015a; Zhang et al. 2015b). Heavy metal contamination in sediments can affect water quality and thus the bioassimilation and bioaccumulation of metals in aquatic organisms, resulting in long-term implications for human and ecosystem health (Ip et al. 2007; Li et al. 2004; Raghunath et al. 1999). A thorough understanding of the depositional characteristics of surface sediments and pollutants is critical for the assessment of heavy metal pollution in marine environments (Xu et al. 2015b; Xu et al. 2015c).

The Pearl River Estuary (PRE) links the Pearl River, which is one of the largest rivers in southern China, and the South China Sea. The Pearl River is composed of three main river channels: West River (Xijiang) is the main channel in the network and is confluent with the East (Dongjiang) and North (Beijiang) Rivers in the lower reaches of the PRE (Lu et al. 2007). The lower alluvial and delta plains of the Pearl 
River are composed of Quaternary fluvial sediments (Lu et al. 2007; Zhang et al. 2007). In recent years, increasing population density and rapid industrial and agricultural development have resulted in severe stress on the aquatic environment of the PRE (Li and Huang 2008) and the introduction of many pollutants carrying heavy metals to the estuarine sediment (Chen et al. 2012). Although considerable effort has been made to investigate heavy metal pollution in PRE sediments (Chen et al. 2012; Ip et al. 2007; Wang et al. 2012; Yang et al. 2012; Ye et al. 2012; Yu et al. 2010), sampling density and heavy metal indexes are limited.

Based on high sampling density and seven heavy metal indexes, the present research aimed to (1) study the spatial distribution of grain size and heavy metals in surface sediments, (2) assess the state of heavy metal contamination using the enrichment factor (EF) and geo-accumulation index (Igeo), and (3) analyze and distinguish the possible sources of heavy metals.

\section{Materials and methods}

\section{Sampling}

We collected 148 surface sediment $(0-5 \mathrm{~cm})$ samples and one $196 \mathrm{~cm}$ long sediment core (SSZ15) from the PRE in January 2008 (Fig. 1). During sampling, each surface sample was placed in a clean cloth bag, and then enclosed in a polyethylene bag in the field. Once returned to the laboratory, the samples were fully air dried at room temperature, sieved through a 10 mesh $(<2 \mathrm{~mm})$ nylon sieve, and then enclosed in a new polyethylene bag individually for later chemical analysis. The core sample was taken with a vibrating sampler and sliced in $4 \mathrm{~cm}$ long sections for grain size, element, and radionuclide analysis.

\section{Laboratory analysis}

Sediment samples were pretreated with $10 \% \mathrm{H}_{2} \mathrm{O}_{2}$ to digest the organic matter. Excessive $\mathrm{H}_{2} \mathrm{O}_{2}$ solution was removed by heating and evaporation. After that, $0.5 \%$ of sodium hexametaphosphate was added to the samples for sediment dispersal, with the mixture then analyzed with a Mastersizer 2000 laser particle-size analyzer (Malvern Ltd., UK) at the Experiment-Testing Center for Marine Geology, Ministry of Land and Resources, China (ISO 17025 laboratory accreditation). Grain-size parameters were calculated following classification from Folk and Ward (1957).

Samples were treated and determined according to the analytical elements. (1) $\mathrm{Cd}$ and $\mathrm{Cu}$ measurements were carried out using inductive coupled plasma mass spectrometry (ICPMS). The samples were dried and ground to $63 \mu \mathrm{m}$ before analysis, and the sediments were digested by adding a mixture of 9:5:2 $\mathrm{HNO}_{3}+\mathrm{HCl}+\mathrm{HF}$ to $0.5 \mathrm{~g}$ of the powdered samples and heating to $180^{\circ} \mathrm{C}$ for $2 \mathrm{~h}$ (GB17378.5, Editorial Board of National Standards Press 1998) in closed Teflon bombs on a heating plate. These digestion steps were repeated with an additional acid until only a negligible amount of white residue remained. Each sample was then leached with diluted $\mathrm{HNO}_{3}$ and the solution was analyzed. (2) As and Hg were analyzed using atomic fluorescence spectrometry (AFS). (3) $\mathrm{Cr}, \mathrm{Pb}, \mathrm{Zn}$, $\mathrm{Al}_{2} \mathrm{O}_{3}, \mathrm{Fe}_{2} \mathrm{O}_{3}, \mathrm{~K}_{2} \mathrm{O}, \mathrm{CaO}, \mathrm{Mn}$, and $\mathrm{Sr}$ were measured by
Fig. 1 Location of the study area and sampling sites

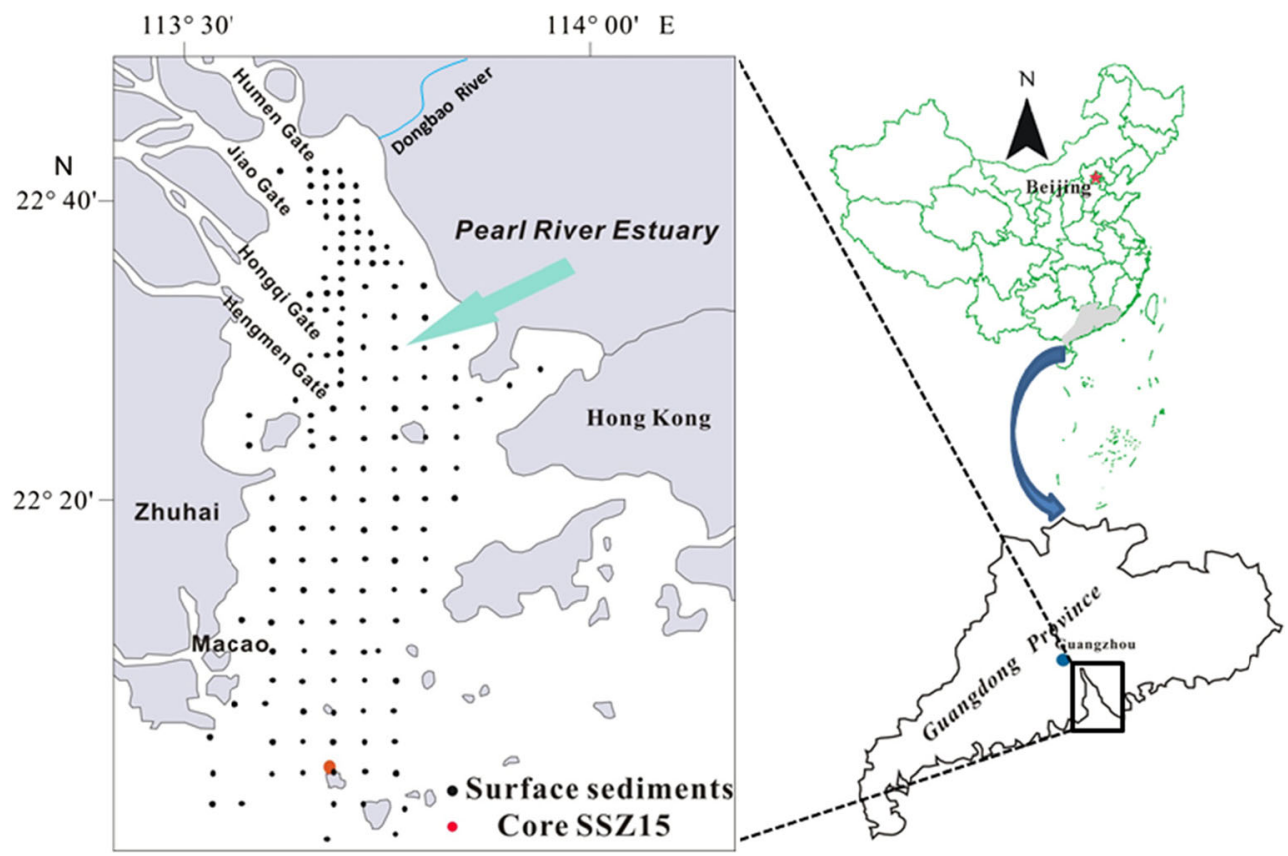


wavelength dispersive X-ray fluorescence spectrometry (PANalytical AXIOS PW4400) after samples were pelletized, as per Xia et al. (2008). Calibration was made using certified reference materials and $\alpha$ correction was applied to correct for matrix interferences. (4) Organic carbon (Corg) was determined by wet oxidation in an acid dichromate solution, followed by back titration of the remaining dichromate using a ferrous ammonium sulfate solution. The analytical methods and detection limits of the above element determinations are listed in Table 1. Sediment reference materials (GBW07317, GSS1, GSS2 and GSS8) were used as analytical quality controls. The recoveries were between 90 and $99 \%$ for all metals, with a precision of $10 \%$.

Both ${ }^{210} \mathrm{~Pb}$ and ${ }^{226} \mathrm{Ra}$ were analyzed using the BE3830 gamma-ray spectrometer (Canberra Co., USA) at the Testing Center of the Qingdao Institute of Marine Geology, China Geological Survey, following a procedure similar to that of Xia et al. (2011). Counting uncertainties associated with sample measurements were typically less than $10 \%$. Supported ${ }^{210} \mathrm{~Pb}$ activities were assumed to be equal to the measured ${ }^{226} \mathrm{Ra}$ activities, and ${ }^{210} \mathrm{~Pb}$ activities $\left({ }^{210} \mathrm{~Pb}_{\mathrm{xs}}\right)$ were calculated by subtracting the supported ${ }^{210} \mathrm{~Pb}$ activities from total ${ }^{210} \mathrm{~Pb}$ activities $\left({ }^{210} \mathrm{~Pb}\right.$ tot $)$ (San Miguel et al. 2004). The sediment accumulation rates were calculated by the constant rate of ${ }^{210} \mathrm{~Pb}$ supply (CRS) model (Appleby and Oldfield 1992). The ${ }^{210} \mathrm{~Pb}$ geochronology was calculated using the equation:

$T=\lambda^{-1} \cdot \ln \left(A_{0} / A_{\mathrm{h}}\right)$

where $A_{0}$ and $A_{\mathrm{h}}$ are the ${ }^{210} \mathrm{~Pb}_{\mathrm{xs}}$ accumulation fluxes below the sediment-water interface and depth $\mathrm{h}$, respectively, and $\lambda$ is the ${ }^{210} \mathrm{~Pb}_{\mathrm{xS}}$ radioactive decay constant $\left(0.03114 \mathrm{year}^{-1}\right)$.

Table 1 Analytical methods and detection limits

\begin{tabular}{|c|c|c|c|}
\hline Indicator & Analytical method & Detection limit & Unit \\
\hline As & AFS & 1 & $\mu \mathrm{g} / \mathrm{g}$ \\
\hline $\mathrm{Cd}$ & ICP-MS & 0.02 & $\mu \mathrm{g} / \mathrm{g}$ \\
\hline $\mathrm{Cr}$ & $\mathrm{XRF}$ & 5 & $\mu \mathrm{g} / \mathrm{g}$ \\
\hline $\mathrm{Cu}$ & ICP-MS & 1 & $\mu \mathrm{g} / \mathrm{g}$ \\
\hline $\mathrm{Hg}$ & AFS & 0.003 & $\mu \mathrm{g} / \mathrm{g}$ \\
\hline $\mathrm{Pb}$ & $\mathrm{XRF}$ & 2 & $\mu \mathrm{g} / \mathrm{g}$ \\
\hline $\mathrm{Zn}$ & $\mathrm{XRF}$ & 2 & $\mu \mathrm{g} / \mathrm{g}$ \\
\hline $\mathrm{Mn}$ & $\mathrm{XRF}$ & 10 & $\mu \mathrm{g} / \mathrm{g}$ \\
\hline $\mathrm{Sr}$ & $\mathrm{XRF}$ & 5 & $\mu \mathrm{g} / \mathrm{g}$ \\
\hline $\mathrm{Al}_{2} \mathrm{O}_{3}$ & $\mathrm{XRF}$ & 0.05 & $\%$ \\
\hline $\mathrm{Fe}_{2} \mathrm{O}_{3}$ & $\mathrm{XRF}$ & 0.05 & $\%$ \\
\hline $\mathrm{K}_{2} \mathrm{O}$ & $\mathrm{XRF}$ & 0.05 & $\%$ \\
\hline $\mathrm{CaO}$ & $\mathrm{XRF}$ & 0.05 & $\%$ \\
\hline Corg. & Electric potential & 0.10 & $\%$ \\
\hline
\end{tabular}

\section{Results and discussion}

\section{Distribution patterns of grain size, Al, heavy metals, and Corg in sediments}

As shown in Fig. 2, the surface sediments in the PRE were dominated by silt, with a certain portion of clay and sand. On average, silt, clay, and sand accounted for 62,22 , and $16 \%$ of the material, respectively. Surface sediments mainly consisted of coarse-grained materials, indicating strong hydrodynamic conditions in the study area. According to Folk and Ward (1957), sediment in this region was classified into mud, silt, sandy mud, sandy silt, and silty sand (Fig. 2). Silt and sandy silt were the most widely distributed sediments, accounting for $84 \%$ of all samples (Fig. 3).

Overall, the distributions of surface sediment yielded a coarse-fine-coarse trend from north to south (Fig. 3). The northern region exhibited sandy deposition due to estuary runoff. Coarse particle distribution was basically parallel to the water channel and was also observed in the northeastern region of Zhuhai City. The middle region displayed transitional deposition, with a mixture of estuary and shelf sea silt. The southern region demonstrated sandy deposition based on its marine environment. Due to anthropogenic influence, especially nearby activities such as desilting and dredging, the original terrain of these regions, particularly that in the north, has been destroyed and depressions and shoals have increased, displaying no regular distribution. Hydrodynamic characteristics have changed, resulting in the diversity of grain size distribution in the PRE surface sediments (Xia 2005). Maximum enrichment of $\mathrm{Al}$ also occurred in the middle region but reduced both north and south. Minimum $\mathrm{Al}$ content was found around Qi-Ao Island, which is covered by silty sand (Fig. 4). Relative higher concentrations of $\mathrm{Fe}_{2} \mathrm{O}_{3}$ were recorded by sediments along the west-side of the PRE (Fig. 4).

The heavy metals (As, $\mathrm{Cd}, \mathrm{Cr}, \mathrm{Cu}, \mathrm{Hg}, \mathrm{Pb}$, and $\mathrm{Zn}$ ) and Corg of the surface sediment samples from the PRE are listed in Table 2. The concentrations of Corg ranged from 0.16 to $1.85 \%$, with an average of $0.9 \%$, which is higher than that of the Changhua River Estuary and adjacent shelf $(0.55 \%)$ (Dou et al. 2013) and the Yangtze River Estuary (0.7 \%) (Zhang et al. 2009a). The spatial distribution of $\mathrm{Cd}$ and $\mathrm{Cu}$ varied considerably, with the coefficients of variation of 79.18 and $48.67 \%$ (Table 2), respectively, demonstrating that these metals might be from point-source input and the similar finding was found in the previous study (Wang et al. 2014a). The spatial distributions of heavy metals and Corg concentrations in the study area are shown in Fig. 4 and, in general, showed similar patterns. Surface heavy metal distributions exhibit different underlying patterns due to different depositional environments, and distinct patterns of distribution have been identified in the PRE (Heise et al. 2010; Woods et al. 2012). Heise et al. (2010) utilizing principle component hierarchical cluster 
Fig. 2 Percentage concentration of sand, silt, and clay (black lines) and sediment classification (red lines) in PRE

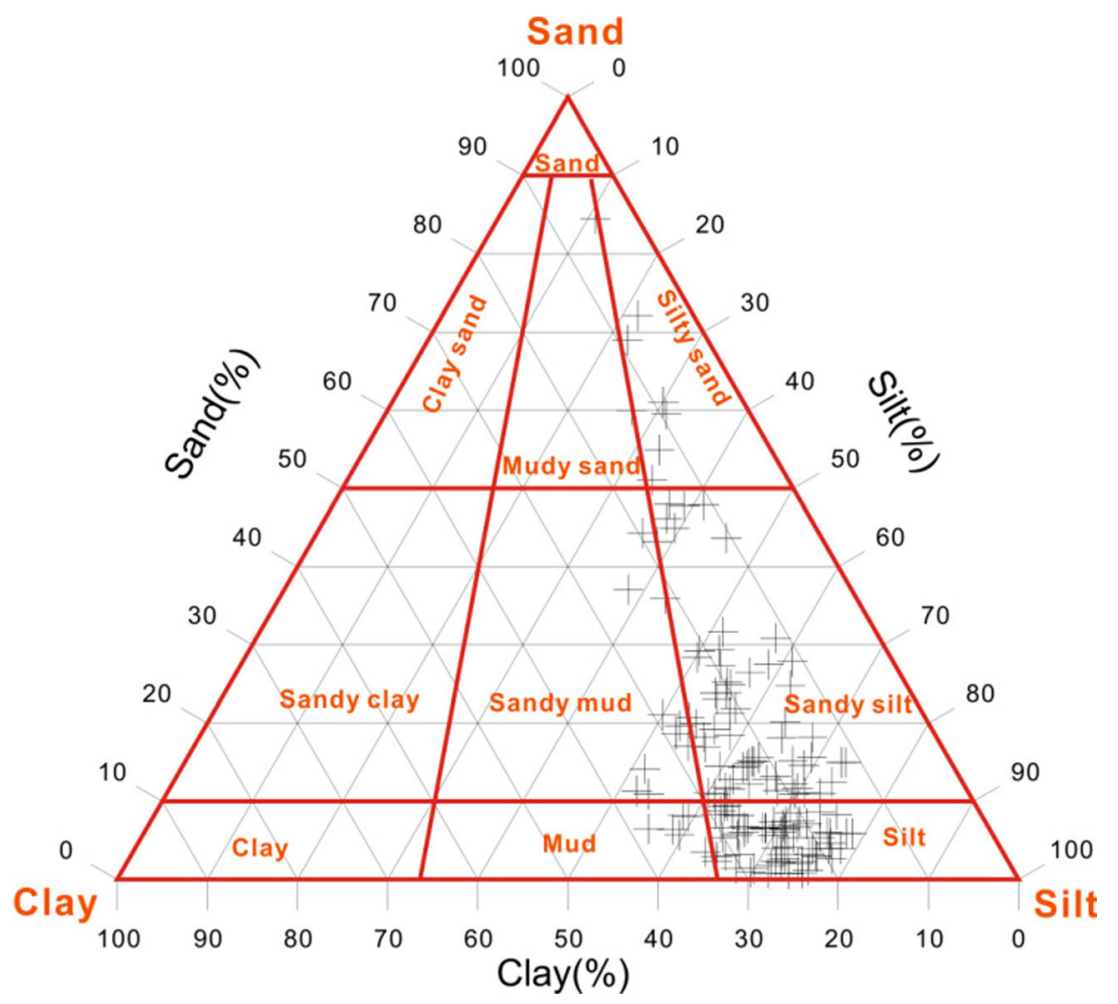

analysis to define and classify the PRE into four distinct areas: class 1 , comprising of mainly coarser sediments; class 2 , consisting of sediments dominated by eroded granite from the northeastern catchment area of the estuary; class 3 , representing the influence of the marine environment and situated in the southernmost part of the outer Ling Ding Yang Estuary; and class 4, consisting of fine sediment deposited at high sedimentation rates and extending from the west to the Ling Ding Yang Channel. As shown in Fig. 4, all heavy metal concentrations decreased in the southeastern part of the estuary, an area with considerable marine influence (class 3), and the northern part of the estuary, an area with coarser sediments (class 1).

The concentrations of $\mathrm{As}, \mathrm{Cr}, \mathrm{Hg}, \mathrm{Pb}, \mathrm{Zn}$, and $\mathrm{Cd}$ were high in the western shoal (class 3), consistent with that of other studies (Li et al. 2000a; Li et al. 2000b; Liu et al. 2003; Peng et al. 2003; Shi et al. 2006). A large number of terrigenous contaminants entering the estuary (Humen Gate, Jiaomen Gate, Hongqimen Gate, and Hengmen Gate) move southwest under the action of Coriolis force and coastal currents (Peng et al. 2003) and were thus deposited with sediments in the western shoal (class 3 ). In addition, mud and silt, which benefit the absorption and deposition of heavy metals (Qian et al. 1996; Zhang et al. 2009b), were widely distributed in the western shoal (Fig. 3). All heavy metals showed lower content in the eastern area (class 2) compared with that in the western shoal (class 3). High concentrations of $\mathrm{Cr}, \mathrm{Cu}$, and $\mathrm{Zn}$ accumulated on a small scale in the northeast of the PRE (Class 2) (Fig. 4), where the Dongbao River from Shenzhen city empties into the Pearl River (Jia et al. 2001). The sewage of the electroplate factory was the important source of $\mathrm{Cr}, \mathrm{Cu}$ and $\mathrm{Zn}$ in Dongbao River (Jia et al. 2001). Thus, the sewage of the electroplate factory likely led to the increase in $\mathrm{Cr}, \mathrm{Cu}$, and $\mathrm{Zn}$ contamination in this area.

The Pearson correlation (PC) coefficients among the heavy metals, major elements, Corg, and clay in the sediments are shown in Table 3. All metals were positively correlated with clay content and Corg, suggesting that sediment size and organic carbon content might exert certain control over the abundance and regional distribution of heavy metals in the surface sediments of the PRE.

Comparisons of the heavy metals in the study area with those of other regions in China are listed in Table 4. Compared with that reported by Yu et al. (2010), the contents of $\mathrm{Cr}, \mathrm{Pb}$, and $\mathrm{Zn}$ in this study were lower, but $\mathrm{Cu}$ was comparable. Contrarily, the contents of $\mathrm{As}, \mathrm{Cd}, \mathrm{Pb}$, and $\mathrm{Zn}$ were higher than those reported by Ye et al. (2012). Furthermore, the concentrations of heavy metals were much higher in the PRE than those reported in Daya Bay, Bohai Bay, and north Shandong Peninsula (Gao et al. 2010; Xu et al. 2015c; Yu et al. 2010). The contents of most heavy metals were higher than those in the South China Sea, Changjiang estuary, and eastern Beibu Bay but equal to that in western Xiamen Bay. Elevated high values of these heavy metals are probably due to the higher degree of industrialization in the Pearl River delta region and the increase in pollution due to rapid industrial development during the last three decades (Zhou et al. 2004). Primary sediment standard criteria are widely applied 
Fig. 3 Spatial distribution of the surface sediment types in PRE

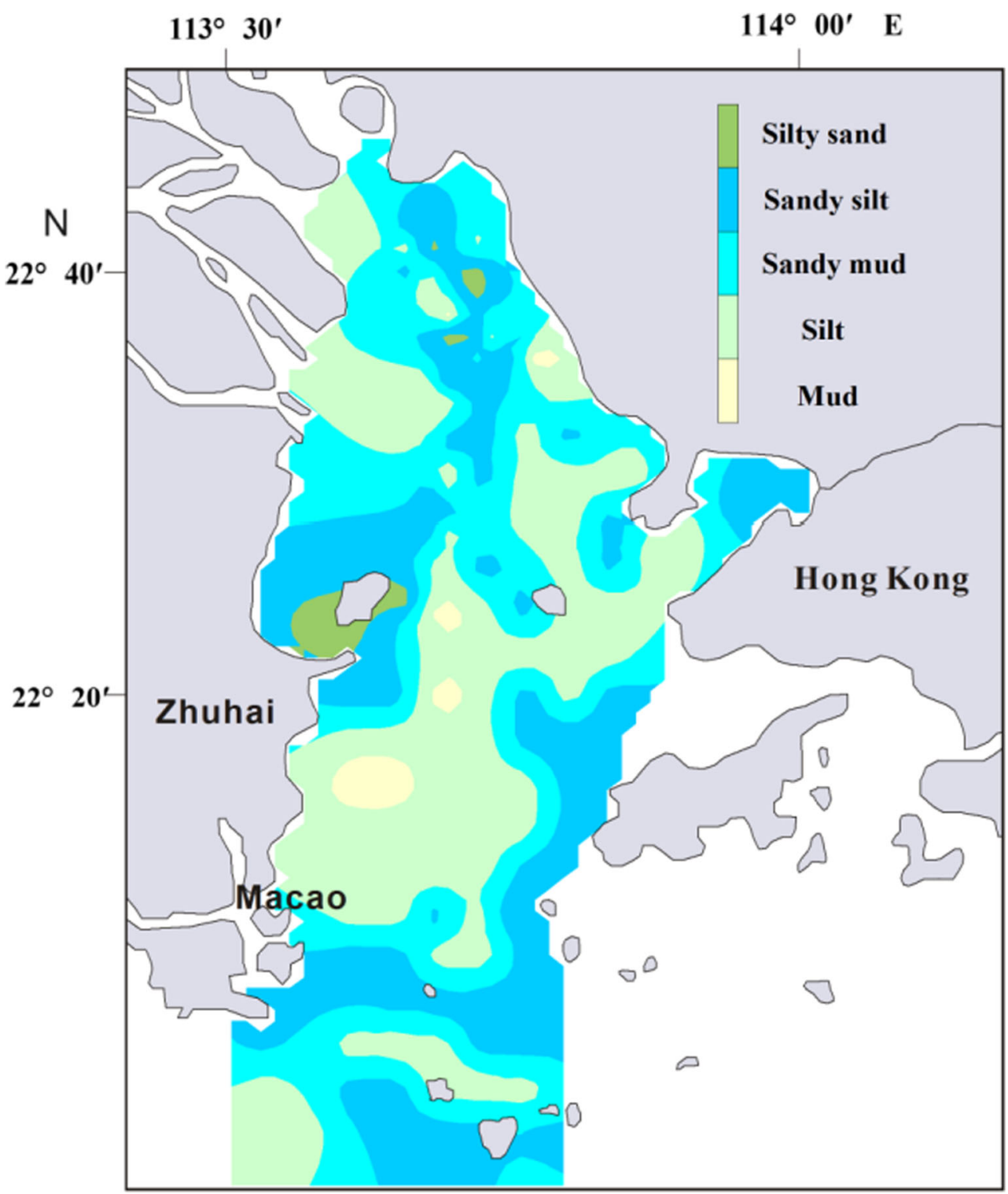

in environmental studies (CSBTS 2002). In comparison with these criteria, the contents of $\mathrm{As}$ and $\mathrm{Cu}$ in the current study were higher, whereas those of $\mathrm{Cd}, \mathrm{Cr}, \mathrm{Hg}, \mathrm{Pb}$, and $\mathrm{Zn}$ were close to the CSBTS. It is worth noting that the background value of $\mathrm{Cu}$ in the South China Sea is equal to that in the CSBTS (Zhang and Du 2005).

\section{Geochronology $\left({ }^{210} \mathrm{~Pb}\right)$ and background values}

The ${ }^{210} \mathrm{~Pb}$ depth profile is shown in Fig. 5. The average sedimentation rate of SSZ15 was $1.48 \mathrm{~cm} / \mathrm{a}$, which is in agreement with the results $(0.5-1.5 \mathrm{~cm} / \mathrm{a})$ of other studies in this region (Chen 1992; Chen and Luo 1991; Ye et al. 2012). The elemental concentration in the Earth's crust (Taylor and McLennan 1995) or abundance of upper crust shale (Rudnick and Gao 2003) is usually used as the baseline value for elements. However, the assessment of contamination levels when compared with a global standard (average shale or crust composition) is not always satisfactory due to the presence of local lithological anomalies (Zhou et al. 2014). Thus, the concentrations of sediments below $150 \mathrm{~cm}$ (about 100 years ago) in the core SSZ15 (12.97 $\mathrm{mg} \mathrm{kg}^{-1}$ for As, $0.14 \mathrm{mg} \mathrm{kg}^{-1}$ for $\mathrm{Cd}, 68 \mathrm{mg} \mathrm{kg}^{-1}$ for $\mathrm{Cr}, 28.9 \mathrm{mg} \mathrm{kg}^{-1}$ for $\mathrm{Cu}, 0.08 \mathrm{mg} \mathrm{kg}^{-1}$ for $\mathrm{Hg}, 33 \mathrm{mg} \mathrm{kg}^{-1}$ for $\mathrm{Pb}$, and $92 \mathrm{mg} \mathrm{kg}^{-1}$ for $\mathrm{Zn}$ ) were selected as the background values in the study area.

\section{Assessment of heavy metal pollution}

The enrichment factor (EF) is widely used to discriminate between natural and anthropogenic sources and to reflect the status of environmental contamination. It is based on the use 

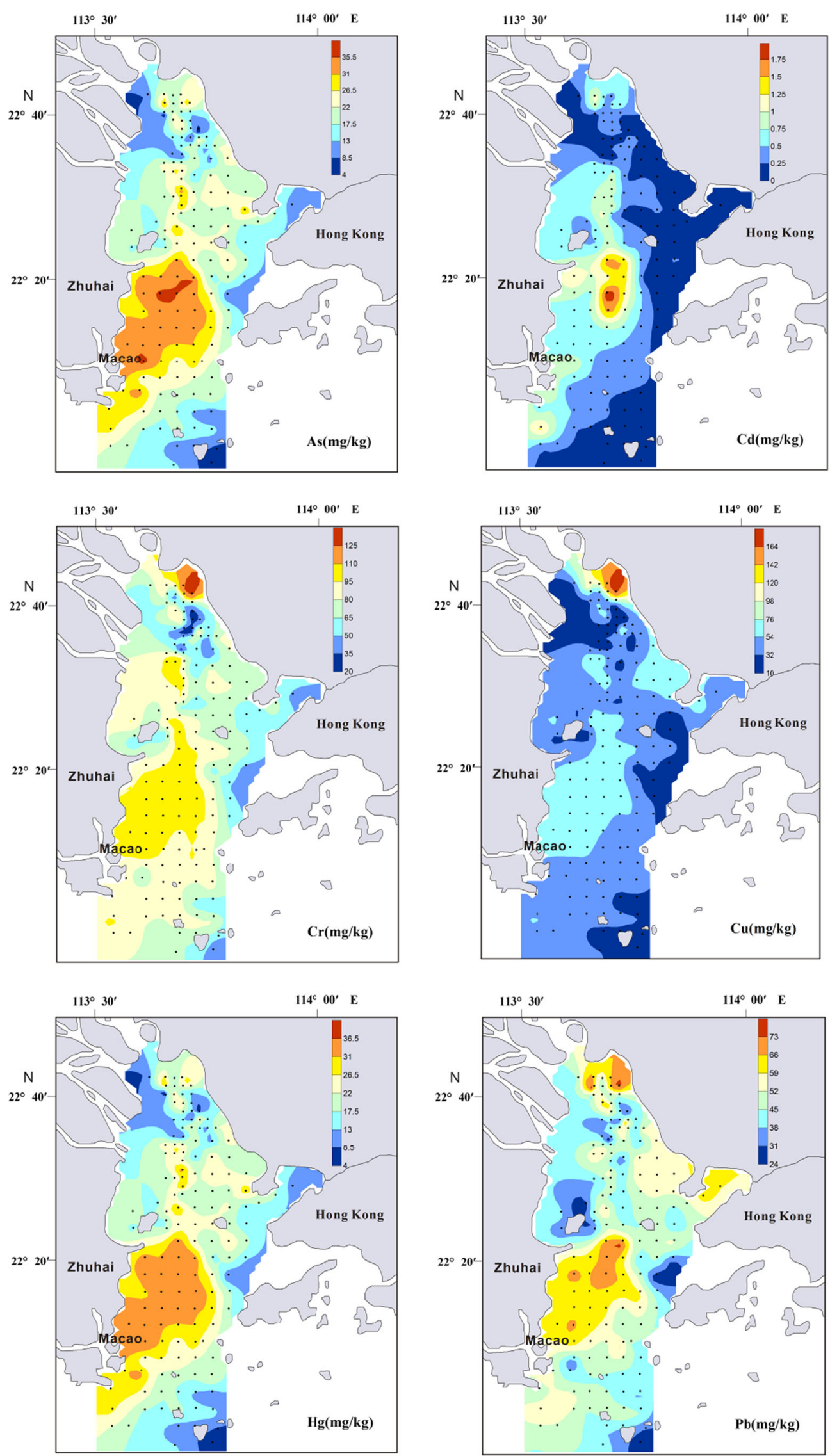

Fig. 4 Concentrations of heavy metals, $\mathrm{Corg}, \mathrm{Al}_{2} \mathrm{O}_{3}$, and $\mathrm{Fe}_{2} \mathrm{O}_{3}$ in the surface sediments of PRE 

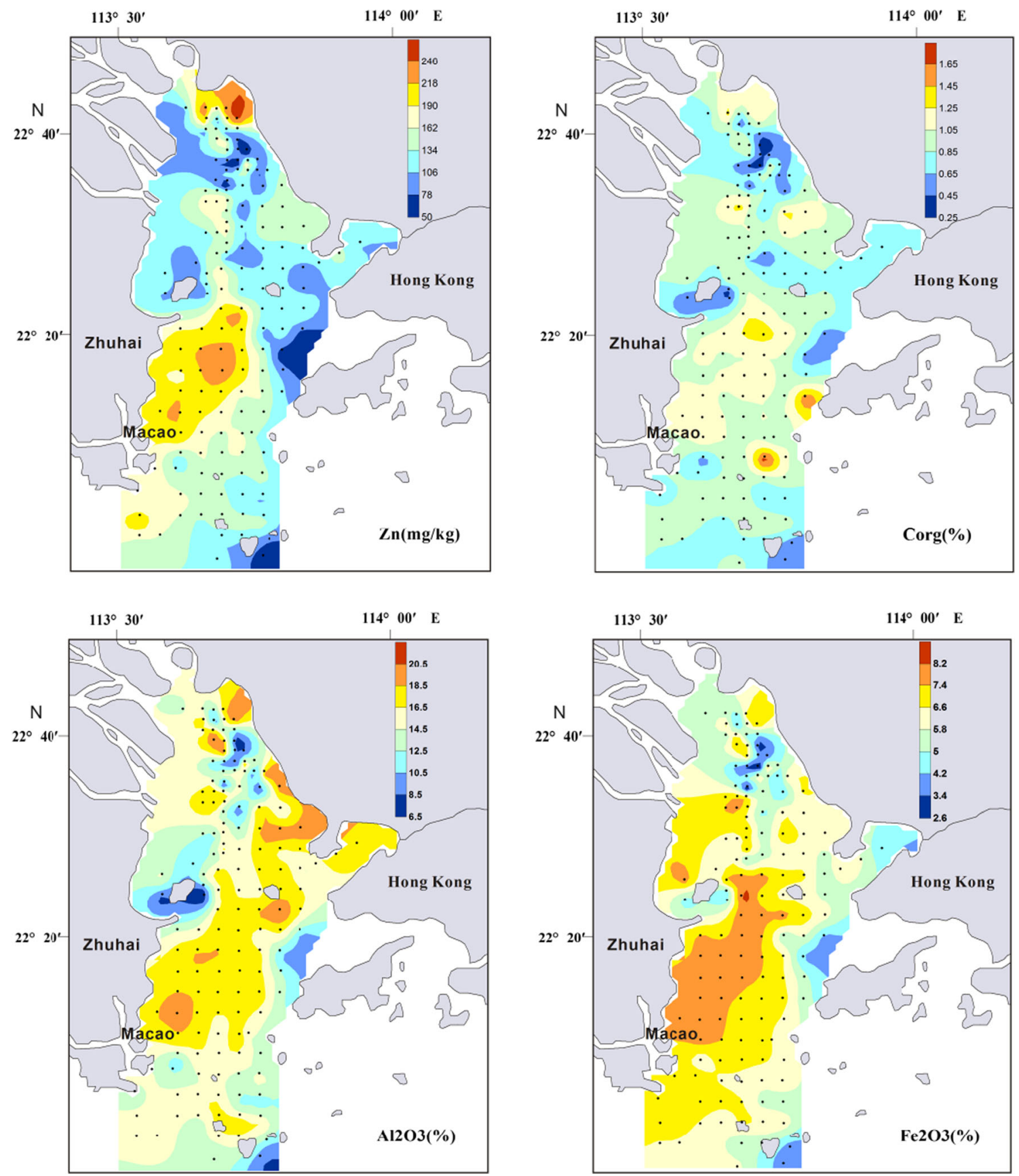

Fig. 4 (continued)

Table 2 Mean grain size, organic carbon (Corg), and heavy metal concentration in the surface sediments of PRE

\begin{tabular}{ccccccccccc}
\hline Station & $\mathrm{Mz}(\varphi)$ & $\mathrm{As}(\mathrm{mg} / \mathrm{kg})$ & $\mathrm{Cd}(\mathrm{mg} / \mathrm{kg})$ & $\mathrm{Cr}(\mathrm{mg} / \mathrm{kg})$ & $\mathrm{Cu}(\mathrm{mg} / \mathrm{kg})$ & $\mathrm{Hg}(\mathrm{mg} / \mathrm{kg})$ & $\mathrm{Pb}(\mathrm{mg} / \mathrm{kg})$ & $\mathrm{Zn}(\mathrm{mg} / \mathrm{kg})$ & $\mathrm{Al}{ }_{2} \mathrm{O}_{3}(\%)$ & $\mathrm{Corg}(\%)$ \\
\hline Min & 2.32 & 3.34 & 0.06 & 12.00 & 5.80 & 0.01 & 23.00 & 32.00 & 5.65 & 0.16 \\
Max & 7.41 & 37.11 & 2.06 & 130.00 & 170.60 & 0.25 & 78.00 & 259.00 & 20.68 & 1.85 \\
Average & 6.29 & 21.99 & 0.46 & 78.37 & 46.76 & 0.13 & 49.66 & 143.10 & 15.24 & 0.90 \\
S.D. & 1.05 & 8.03 & 0.37 & 22.42 & 22.76 & 0.05 & 11.66 & 47.93 & 3.48 & 0.26 \\
C.V. & $16.63 \%$ & $36.49 \%$ & $79.18 \%$ & $28.60 \%$ & $48.67 \%$ & $39.51 \%$ & $23.48 \%$ & $33.49 \%$ & $22.83 \%$ & $28.69 \%$ \\
\hline
\end{tabular}

Mz mean grain size, Min minimum values, Average average values, S.D. standard deviation, C.V. coefficient of variation 
of a normalization element to alleviate the variations produced by heterogeneous sediments (Bastami et al. 2012; Christophoridis et al. 2009; Siddique et al. 2009; Xu et al. 2015a) and is calculated using the following equation:

$\mathrm{EF}=\left(C_{n} / X\right)_{\text {Sample }} /\left(C_{n} / X\right)_{\text {baseline }}$

where $C_{n}$ is the concentration of the considered element, and $X$ is the normalization element. It was found that the relative proportion of a metal to $\mathrm{Al}$ in crustal material is fairly constant (Taylor 1964; Turekian and Wedepohl 1961). The ratio of heavy metals to Al can minimize the grain size effect between measured content and baseline values and reveal actual geochemical imbalance (Din 1992; Schropp et al. 1990). However, the use of a single element for normalization does not constrain which elements are enriched by human activities if used across the entire PRE, and it may be possible to better identify which elements are truly enriched by identifying and utilizing a normalization method appropriate to that region (Woods et al. 2012). Relative higher concentrations of $\mathrm{Fe}_{2} \mathrm{O}_{3}$ were found along the west-side of the study region (Fig. 4). In the case of the west side of the PRE, where Fe contents were elevated, the element Fe was therefore applied for normalization, while Al was used for the rest study areas. EF values between 0.5 and $1.5(0.5<\mathrm{EF}<1.5)$ indicate that the metals are entirely from crustal material or natural weathering processes, whereas EF values greater than 1.5 indicate an important proportion of noncrustal materials (e.g., anthropogenic influences) (Zhang and Liu 2002). The EF ranges of the heavy metals in the present study were as follows: As, 0.37-2.70 (average 1.49); Cd, 0.49-10.82 (average 2.9); Cr, 0.44-1.88 (average 1.01); $\mathrm{Cu}, 0.48-4.08$ (average 1.39); Hg, 0.4-2.96 (average 1.45); $\mathrm{Pb}, 0.72-2.32$ (average 1.36); and $\mathrm{Zn}, 0.79$ 2.64 (average 1.37). As shown in Fig. 6, the mean EF values of As and $\mathrm{Hg}$ were close to 1.5 , suggesting a certain potential risk. The EF values of $\mathrm{Cd}$ (2.9) were more than 1.5 in all sampled areas, indicating significant $\mathrm{Cd}$ contamination in the study area.

The Igeo, another commonly used criterion, was originally defined by Müller (1979) to evaluate heavy metal contamination in sediments by comparing current concentrations with pre-industrial levels and is defined by the following equation:

$\mathrm{I}_{\text {geo }}=\log _{2}\left[\left(C_{n} / X\right) /\left(1.5 \times B_{\mathrm{n}}\right) / X\right]$

where $C_{n}$ is the measured concentration of the examined metal (n) in the sediment, $B_{n}$ is the background concentration of the metal $(n)$, and factor 1.5 is the background matrix correction factor due to lithogenic effects. $X$ is element for the normalization. Similar to the computations of EFs, elements Fe and $\mathrm{Al}$ were used separately in the western region and the rest of the regions as the normalization elements, The seven Igeo classes range from class 0 (Igeo $\leq 0$ ) to class 6 (Igeo $>5$ ) (Müller 1981). The Igeo values of the heavy metals in this study are 
Table 4 Comparison of heavy metal of surface sediments in PRE(unit: $\mathrm{mg} / \mathrm{kg}$ )

\begin{tabular}{lccccccccc}
\hline Location & As & $\mathrm{Cd}$ & $\mathrm{Cr}$ & $\mathrm{Cu}$ & $\mathrm{Hg}$ & $\mathrm{Pb}$ & $\mathrm{Zn}$ & $\mathrm{Reference}$ \\
\hline Study area & Average & 21.99 & 0.46 & 78.37 & 46.76 & 0.13 & 49.66 & 143.10 & This study \\
Pearl River Estuary, China & na & na & 106 & 45.7 & na & 57.9 & 176.8 & Yu et al.(2010) \\
Pearl River Estuary, China & 17.42 & 0.29 & na & na & na & 40.51 & 109.49 & Ye et al.(2012) \\
Daya Bay, China & na & na & 75.6 & 12.7 & na & 32.7 & 94.4 & Yu et al.(2010) \\
Daya Bay, China & na & 0.052 & na & 20.8 & na & 45.7 & 113 & Gao et al.(2010) \\
Western Xiamen Bay,China & na & 0.33 & 75 & 44 & na & 50 & 139 & Zhang et al.(2007) \\
Eastern Beibu Bay, China & 9.53 & 0.16 & 53.65 & 58.26 & 0.06 & 27.99 & 67.28 & Dou et al.(2013) \\
Southern Bohai Bay, China & na & 0.14 & 33.5 & 22.7 & na & 21.7 & 71.7 & Hu et al.(2013c) \\
Liaodong Bay, China & 8.3 & na & 46.4 & 19.4 & 0.04 & 31.8 & 71.7 & Hu et al.(2013c) \\
Changjiang Estuary, China & na & 0.26 & 78.9 & 30.7 & na & 31.8 & 94.3 & Zhang et al.(2009a) \\
South China Sea, China & na & 0.40 & 105 & 38.1 & na & 23.6 & 87.4 & Zhu et al.(2011) \\
Near-shore area, north Shandong Peninsula, China & 8.9 & 0.09 & 59 & 18.7 & na & 18.2 & 61 & Xu et al.(2015c) \\
Primary standard, China & 20 & 0.5 & 80 & 35 & 0.2 & 60 & 150 & CSBTS(2002) \\
\hline
\end{tabular}

shown in Fig. 7 and ranged from -2.03 to 0.85 for As (average -0.08 ), -1.62 to 2.85 for $\mathrm{Cd}$ (average 0.63 ), -1.78 to 0.33 for $\mathrm{Cr}$ (average -0.59 ), -1.63 to 1.44 for $\mathrm{Cu}$ (average -0.20 ), -1.92 to 0.98 for $\mathrm{Hg}$ (average -0.12 ), -1.01 to 0.63 for $\mathrm{Pb}$ (average -0.17 ), and -0.92 to 0.81 for $\mathrm{Zn}$ (average -0.17 ). According to the Müller scale (Müller 1981), the Igeo values indicate no $\mathrm{As}, \mathrm{Cr}, \mathrm{Cu}, \mathrm{Hg}, \mathrm{Pb}$, or $\mathrm{Zn}$ pollution in the study area as a whole, although some deviation was observed depending on the metal and sampling location. The Igeo value for $\mathrm{Cd}$ was between 0 and 1 , generally indicating slight to moderate pollution in the PRE.

\section{Sources and transport of heavy metals}

Principle component analysis (PCA) is a common multivariate method used in environmental studies to investigate potential pollution sources (natural or anthropogenic) and their element characteristics (Han et al. 2006; Hu et al. 2013b; Li et al. 2013; Varol 2011). The rotated component matrixes of the PCA are presented in Table 5. The Kaiser-Meyer-Olkin (KMO) and Bartlett's values were 0.853 and 3047.898 $(\mathrm{df}=105$, Sig $<0.01)$, suggesting that PCA might be useful in dimensionality reductions. The first three principal
Fig. 5 Profile distributions of ${ }^{210} \mathrm{~Pb}$ and ${ }^{210} \mathrm{~Pb}$-derived chronology from the core SSZ15

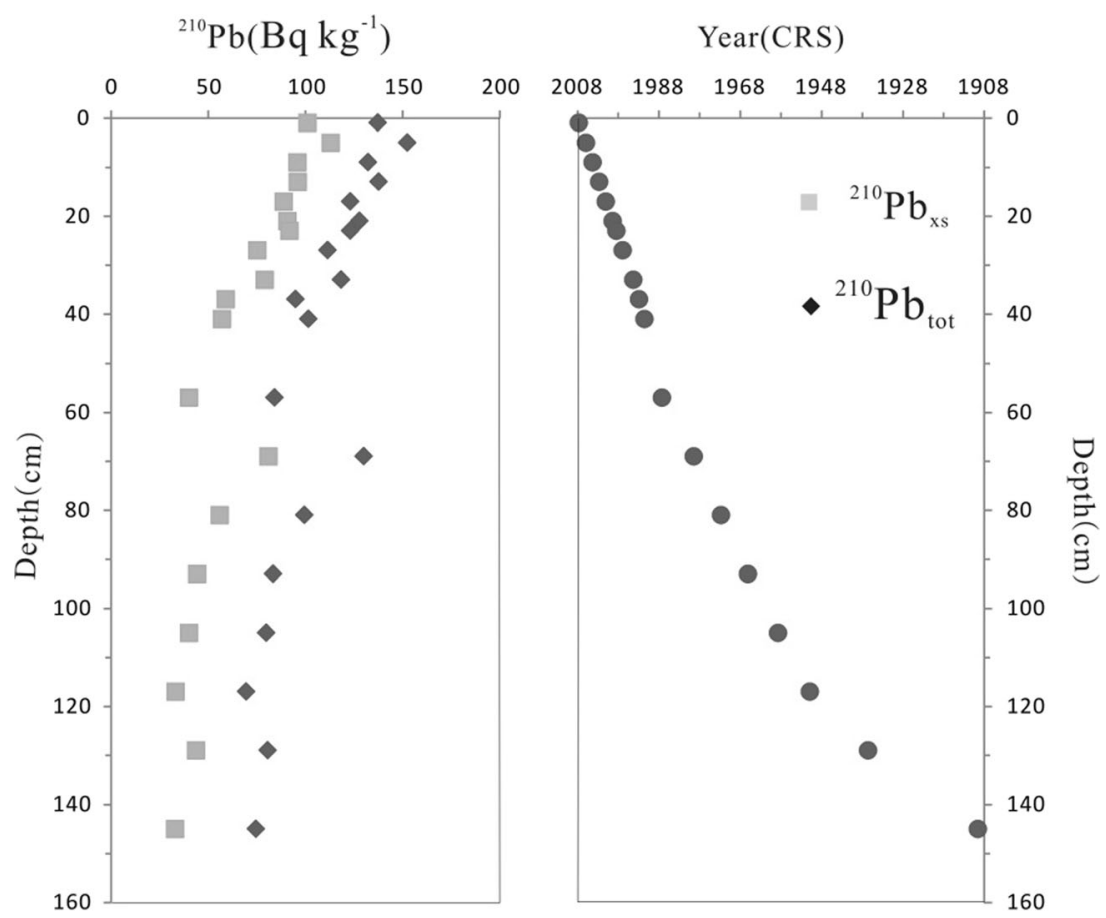




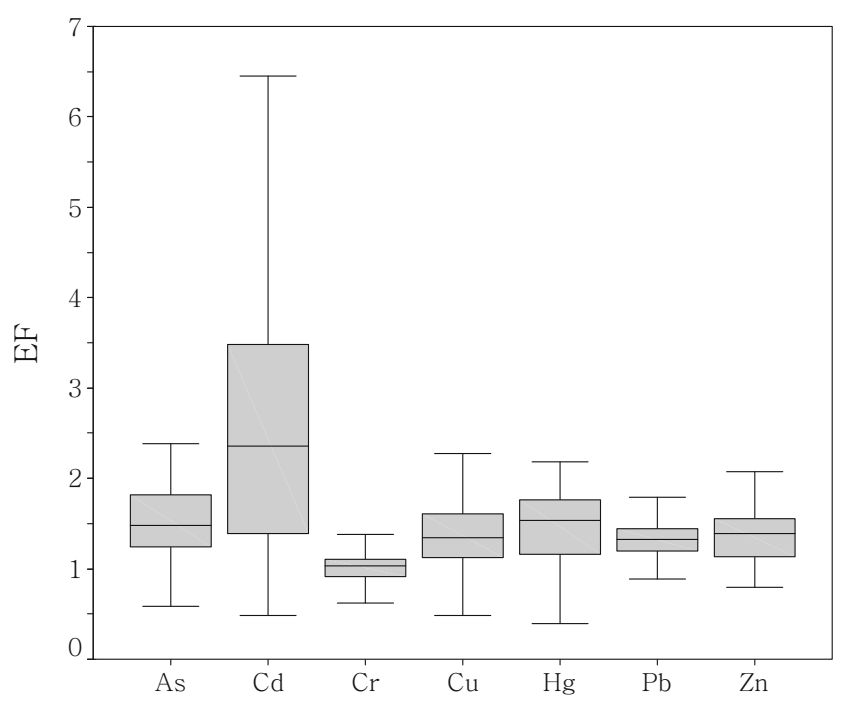

Fig. 6 Enrichment factor (EF) of heavy metals in the surface sediments of PRE

components accounted for $81.37 \%$ of total variance. The loading plot of the first three principal components of the surface samples is depicted in Fig. 8.

The first principal component (PC1), with high loadings of $\mathrm{As}, \mathrm{Cd}, \mathrm{Hg}, \mathrm{Cr}, \mathrm{Cu}, \mathrm{Zn}, \mathrm{Pb}, \mathrm{Fe}_{2} \mathrm{O}_{3}, \mathrm{Mn}$, and Corg, accounted for $46.30 \%$ of total variance (Table 5). Both EF and Igeo results indicated that $\mathrm{Cd}$ was clearly influenced by anthropogenic inputs, with $\mathrm{As}$ and $\mathrm{Hg}$ showing potential risk. Therefore, $\mathrm{PC} 1$ can be regarded as an "anthropogenic factor" mainly related to the discharge of industrial and agricultural wastewater and untreated urban sewage. Anthropogenic sources of heavy metals have been demonstrated in many estuaries worldwide (Diop et al. 2015; Jayaprakash et al. 2014; Pérez-López et al. 2011).

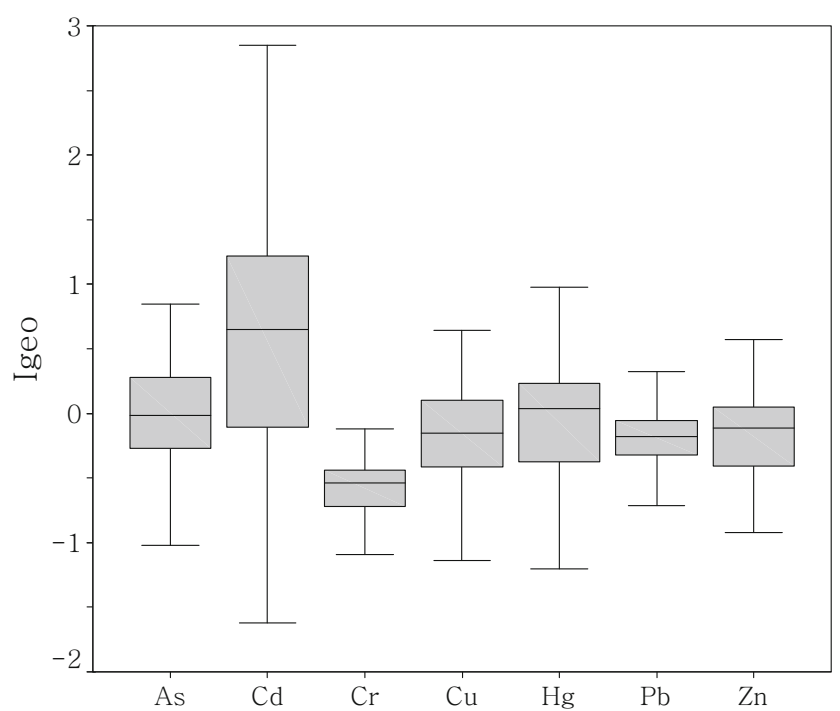

Fig. 7 Geo-accumulation index $\left(\mathrm{I}_{\text {geo }}\right)$ of heavy metals in the surface sediments of PRE
Table 5 Total variance explained and rotated component matrix of principal components analysis

\begin{tabular}{lccc}
\hline Elements & PC1 & PC2 & PC3 \\
\hline $\mathrm{As}$ & 0.856 & 0.277 & -0.180 \\
$\mathrm{Cd}$ & 0.840 & -0.085 & -0.172 \\
$\mathrm{Cr}$ & 0.859 & 0.402 & 0.026 \\
$\mathrm{Cu}$ & 0.704 & 0.394 & -0.213 \\
$\mathrm{Hg}$ & 0.924 & 0.241 & -0.127 \\
$\mathrm{~Pb}$ & 0.660 & 0.619 & -0.149 \\
$\mathrm{Zn}$ & 0.876 & 0.373 & -0.124 \\
$\mathrm{Corg}$. & 0.654 & 0.509 & 0.46 \\
$\mathrm{Al} \mathrm{O}_{3}$ & 0.488 & 0.830 & 0.69 \\
$\mathrm{Clay}$ & 0.440 & 0.421 & 0.100 \\
$\mathrm{Fe} \mathrm{O}_{3}$ & 0.827 & 0.435 & 0.117 \\
$\mathrm{Sr}$ & -0.055 & 0.146 & 0.965 \\
$\mathrm{CaO}$ & -0.104 & -0.195 & 0.954 \\
$\mathrm{~K}_{2} \mathrm{O}$ & 0.038 & 0.920 & -0.101 \\
$\mathrm{Mn}$ & 0.811 & 0.097 & 0.070 \\
$\%$ of variance & 46.30 & 21.41 & 13.66 \\
$\%$ of cumulative & 46.30 & 67.71 & 81.37 \\
\hline
\end{tabular}

Extraction method: principal component analysis. Rotation method: varimax with Kaiser normalization. Rotation converged in three iterations

In the PRE sediments, $\mathrm{Cd}, \mathrm{Cu}, \mathrm{Pb}$, and $\mathrm{Zn}$ were significantly derived from anthropogenic sources (Li et al. 2001; Li et al. 2000b; Taylor and McLennan 1995; Zhou et al. 2004). This element group portrayed the anthropogenic input and accumulation in the estuarine sediments. According to studies on the chemical phase of metals in estuarine sediments, Fe/Mn oxides and organic/sulfide fractions are important geochemical phases for heavy metals in sediments, except for the dominant residual fraction (e.g., $\mathrm{Cr}, \mathrm{Hg}$, and $\mathrm{Zn}$ are mainly associated with the $\mathrm{Fe}-\mathrm{Mn}$ oxide fraction; $\mathrm{Cu}$ and $\mathrm{Pb}$ are associated with the organic fraction) (Li et al. 2000a; Li et al. 2000b; Liu et al. 2003). In this study, Fe, Mn, and Corg showed high correlation with other elements in this group (Table 3), suggesting that heavy metals retained in the sediments bound preferentially to the Fe-Mn oxide fraction or organic matter.

The second principal component ( $\mathrm{PC} 2,21.41 \%$ of total variance) had strong loadings on $\mathrm{K}_{2} \mathrm{O}$ and $\mathrm{Al}_{2} \mathrm{O}_{3}$ and moderate loadings for Corg, $\mathrm{Fe}_{2} \mathrm{O}_{3}$, clay, $\mathrm{Pb}, \mathrm{Cr}, \mathrm{Zn}$, and $\mathrm{Cu}$. Both $\mathrm{Al}$ and $\mathrm{K}$ are major constituents of common silicate minerals. Aluminum is extremely immobile in the marine environment and is usually held in a lattice of aluminosilicate minerals and regarded as a typical lithogenic element (Price et al. 1999). Therefore, Al and $\mathrm{K}_{2} \mathrm{O}$ mainly represent lithogenic origin from weathering and erosion of rocks and soil parent materials in the Pearl River catchment. Correspondingly, terrigenous 


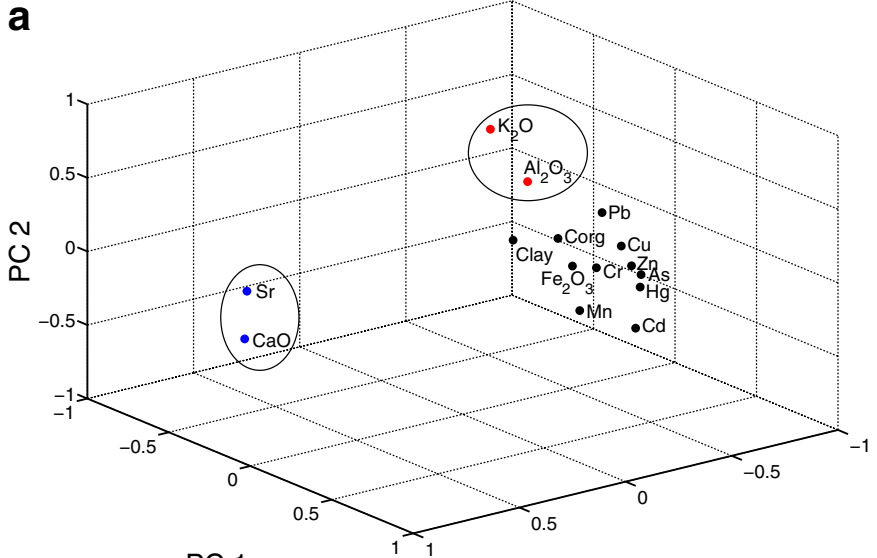

PC 1

C

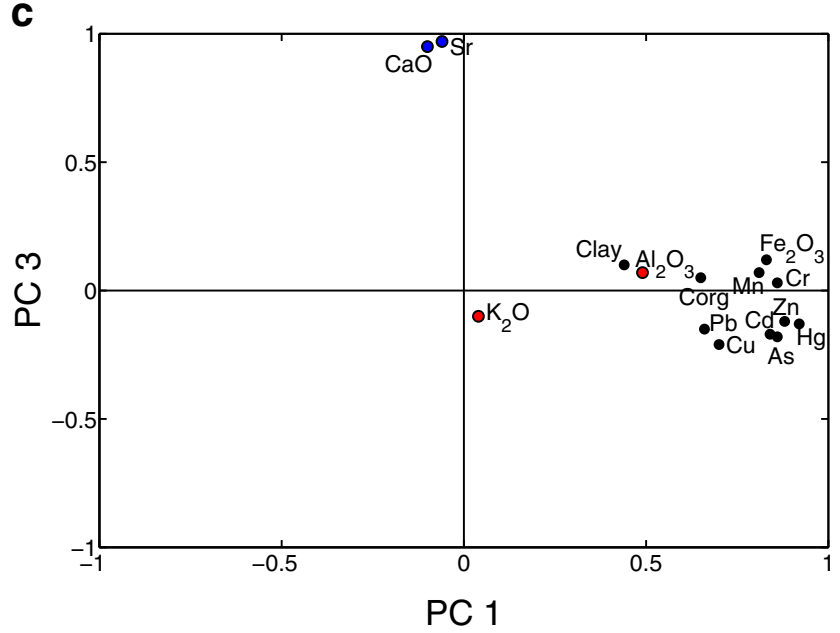

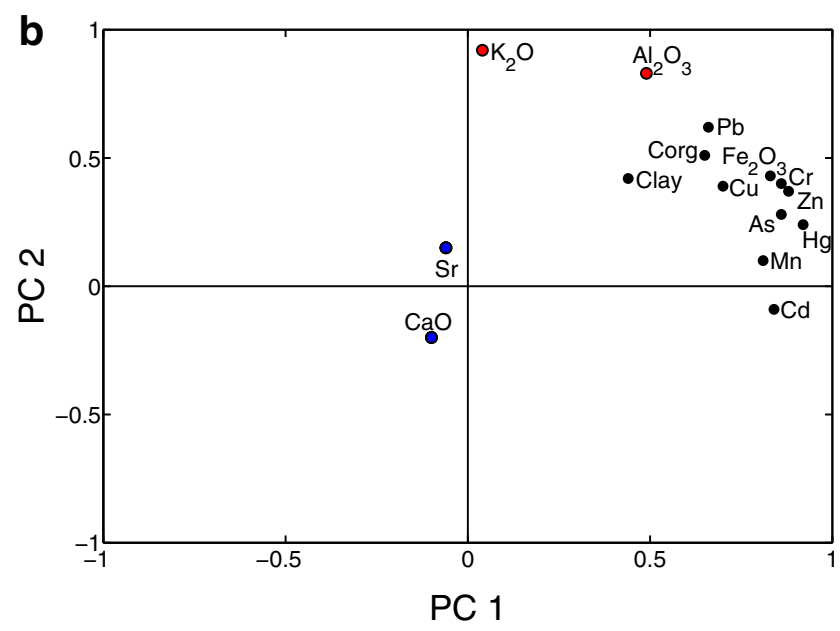

d

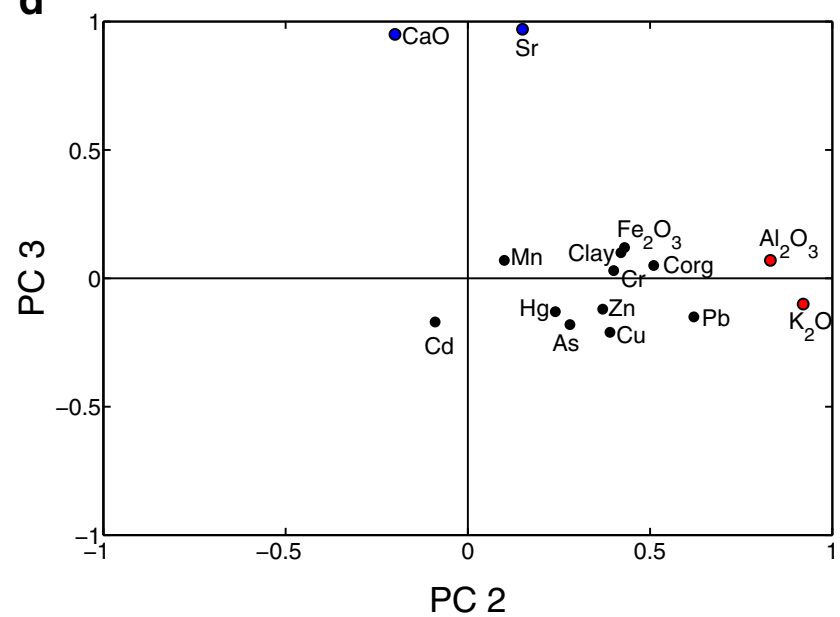

Fig. 8 Principal component loading of heavy metals, major elements, Corg, and clay

sources of $\mathrm{Al}$ and $\mathrm{K}$ have also been observed in previous studies (Peng et al. 2003; Qi et al. 2010). In addition, the lithogenic elements ( $\mathrm{Al}$ and $\mathrm{K}$ ) are proportional to most anthropogenic elements, as expressed by their positive correlations in this study (Table 3). Moreover, PCA showed that $\mathrm{Pb}, \mathrm{Cr}, \mathrm{Zn}, \mathrm{Cu}, \mathrm{Fe}$, and Corg had moderate loadings on PC2, indicating that these elements were derived, at least partially, from lithogenic sources bound in aluminosilicate minerals. Fine clay particles are an important carrier of trace metals to the coastal area (Ip et al. 2007; Yu et al. 2008).

The third principal component (PC3, 13.66\% of total variance) demonstrated strong positive loadings for $\mathrm{CaO}$ and $\mathrm{Sr}$, weak positive loading for Al and negative loading for $\mathrm{K}$. Both $\mathrm{Ca}$ and $\mathrm{Sr}$ are essential components of marine biota and play an important role in the marine biogeochemical cycle. Furthermore, $\mathrm{CaO}$ and $\mathrm{Sr}$ are related to marine sedimentation processes and mainly originate from marine calcic biota (Barcellos et al. 1997; Rubio et al. 2000). The correlation coefficient between $\mathrm{CaO}$ and $\mathrm{Sr}$ reached 0.854 (Table 3), indicating that $\mathrm{CaO}$ and $\mathrm{Sr}$ probably originated from the same source. Similar findings in the PRE have been reported in other research (Zhou et al. 2004). Therefore, PC3 was characterized by a marine component.

\section{Conclusions}

This study demonstrated that surface sediments in the study area were dominated by silt and sandy silt, indicating strong hydrodynamic conditions. The spatial distribution patterns of heavy metal concentrations were closely related to sediment type. Overall, $\mathrm{Cd}, \mathrm{Cr}, \mathrm{Hg}, \mathrm{Pb}$, and $\mathrm{Zn}$ in these sediments met the primary standard criteria of China (CSBTS 2002), though $\mathrm{As}$ and $\mathrm{Cu}$ did not. The heavy metal concentrations increased within the compositional range of other intertidal sediments in China. Both EF and Igeo showed slight to moderate Cd contamination in the PRE. Cd pollution, which was the most significant in the PRE, had negative loadings with PC2 and PC3, suggesting that $\mathrm{Cd}$ could be from anthropogenic sources. 
Both As and $\mathrm{Hg}$ appeared to mainly originate from human activity, whereas $\mathrm{Pb}, \mathrm{Cr}, \mathrm{Cu}$, and $\mathrm{Zn}$ were supplied from both natural and anthropogenic sources.

Acknowledgments This study was jointly funded by the Natural Science Foundations of China (Grant No. 41406082, 40872167, 41240022), Shandong Provincial Natural Science Foundation (Grant No. ZR2014DQ010), and Governmental Public Research Funds of China (Nos.PSGD20731059C01B09, 201111023, GZH201200503, and 121201005000150004). This manuscript benefitted from the constructive comments of two anonymous reviewers.

Open Access This article is distributed under the terms of the Creative Commons Attribution 4.0 International License (http:// creativecommons.org/licenses/by/4.0/), which permits unrestricted use, distribution, and reproduction in any medium, provided you give appropriate credit to the original author(s) and the source, provide a link to the Creative Commons license, and indicate if changes were made.

\section{References}

Appleby PG, Oldfield F (1992) Application of lead-210 to sedimentation studies. In: Ivanovich M, Harmon RS (eds) Uranium-series disequilibrium applications to Earth. Clarendon Press, Oxford, pp. 731-783

Barcellos C, De Lacerda L, Ceradini S (1997) Sediment origin and budget in Sepetiba Bay (Brazil) — an approach based on multielemental analysis. Environ Geol 32:203-209

Bastami KD, Bagheri H, Haghparast S, Soltani F, Hamzehpoor A, Bastami MD (2012) Geochemical and geo-statistical assessment of selected heavy metals in the surface sediments of the Gorgan Bay, Iran. Mar Pollut Bull 64:2877-2884

Chen B, Liang X, Xu W, Huang X, Li X (2012) The changes in trace metal contamination over the last decade in surface sediments of the Pearl River Estuary, South China. Sci Total Environ 439:141-149

Chen Y, Luo Z (1991) Modern sedimentary velocity and their reflected sedimentary characteristics in the Pearl River mouth. Trop Oceanol 10:57-64

Chen Y (1992) Modern sedimentary velocity and sedimentary environment in the Pearl River mouth. Acta Scientiarum Naturalium University Sunyatseni 31:100-107

Christophoridis C, Dedepsidis D, Fytianos K (2009) Occurrence and distribution of selected heavy metals in the surface sediments of Thermaikos Gulf, N. Greece. Assessment using pollution indicators. J Hazard Mater 168:1082-1091

CSBTS (2002) Marine sediment quality. Standards Press of China, Beijing

Din ZB (1992) Use of aluminium to normalize heavy-metal data from estuarine and coastal sediments of straits of Melaka. Mar Pollut Bull 24:484-491

Diop C, Dewaelé D, Cazier F, Diouf A, Ouddane B (2015) Assessment of trace metals contamination level, bioavailability and toxicity in sediments from Dakar coast and Saint Louis estuary in Senegal, West Africa. Chemosphere 138:980-987

Dou Y, Li J, Zhao J, Hu B, Yang S (2013) Distribution, enrichment and source of heavy metals in surface sediments of the eastern Beibu Bay, South China Sea. Mar Pollut Bull 67:137-145

Editorial Board of Chinese standards (1998) National Standards of the People's Republic of China, National Standards Press

Folk RL, Ward WC (1957) Brazos River bar: a study in the significance of grain size parameters. J Sediment Res 27
Gao X, Arthur Chen C-T, Wang G, Xue Q, Tang C, Chen S (2010) Environmental status of Daya Bay surface sediments inferred from a sequential extraction technique. Estuar Coast Shelf Sci 86:369-378

Han YM, Du PX, Cao JJ, Posmentier ES (2006) Multivariate analysis of heavy metal contamination in urban dusts of Xi'an, Central China. Sci Total Environ 355:176-186

Heise B, Bobertz B, Harff J (2010) Classification of the Pearl River estuary via principal component analysis and regionalisation. $\mathrm{J}$ Coastal Res 769-779

Hu B, Cui R, Li J, Wei H, Zhao J, Bai F, Song W, Ding X (2013a) Occurrence and distribution of heavy metals in surface sediments of the Changhua River estuary and adjacent shelf (Hainan Island). Mar Pollut Bull 76:400-405

Hu B, Li G, Li J, Bi J, Zhao J, Bu R (2013b) Spatial distribution and ecotoxicological risk assessment of heavy metals in surface sediments of the southern Bohai Bay, China. Environ Sci Pollut Res 20:4099-4110

Hu B, Li J, Zhao J, Yang J, Bai F, Dou Y (2013c) Heavy metal in surface sediments of the Liaodong Bay, Bohai Sea: distribution, contamination, and sources. Environmental Monitoring and Assessment 185: 5071-5083

Ip C, Li X, Zhang G, Farmer J, Wai O, Li Y (2004) Over one hundred years of trace metal fluxes in the sediments of the Pearl River Estuary, South China. Environ Pollut 132:157-172

Ip CC, Li X-D, Zhang G, Wai OW, Li Y-S (2007) Trace metal distribution in sediments of the Pearl River Estuary and the surrounding coastal area, South China. Environ Pollut 147:311-323

Jayaprakash M, Viswam A, Gopal V, Muthuswamy S, Kalaivanan P, Giridharan L, Jonathan M (2014) Bioavailable trace metals in micro-tidal Thambraparani estuary, Gulf of Mannar, SE coast of India. Estuar Coast Shelf Sci 146:42-48

Jia Z, Zhao Z, Yang X, Liu J, Chen Z (2001) Pollution and assessment of heavy metals in Yangchong River, Maozhou River and Dongbao River sediments, Shenzhen. Environ Chem 20:212-219

Li B, Huang GQ (2008) Ecology effect and countermeasure of urbanization in Pearl River Estuary. Mar Environ Sci 27

Li G, Cao Z, Lan D, Xu J, Wang S, Yin W (2007) Spatial variations in grain size distribution and selected metal contents in the Xiamen Bay, China. Environ Geol 52:1559-1567

Li G, Hu B, Bi J, Leng Q, Xiao C, Yang Z (2013) Heavy metals distribution and contamination in surface sediments of the coastal Shandong Peninsula (Yellow Sea). Mar Pollut Bull 76:420-426

Li X, Shen Z, Wai OW, Li Y-s (2000a) Chemical partitioning of heavy metal contaminants in sediments of the Pearl River Estuary. Chemical Speciation \& Bioavailability 12:17-25

Li X, Wai OW, Li Y, Coles BJ, Ramsey MH, Thornton I (2000b) Heavy metal distribution in sediment profiles of the Pearl River estuary, South China. Appl Geochem 15:567-581

Li X, Shen Z, Wai OW, Li Y-S (2001) Chemical forms of Pb, Zn and $\mathrm{Cu}$ in the sediment profiles of the Pearl River Estuary. Mar Pollut Bull 42:215-223

Li X, Lee S-1, Wong S-c, Shi W, Thornton I (2004) The study of metal contamination in urban soils of Hong Kong using a GIS-based approach. Environ Pollut 129:113-124

Liu W, Li X, Shen Z, Wang D, Wai O, Li Y (2003) Multivariate statistical study of heavy metal enrichment in sediments of the Pearl River Estuary. Environ Pollut 121:377-388

Lu X, Zhang S, Xie S, Ma P (2007) Rapid channel incision of the lower Pearl River (China) since the 1990 s as a consequence of sediment depletion. Hydrol Earth Syst Sci Discuss 11:1897-1906

Müller G (1979): Heavy metals in the surfaces sediment of the RhineChanges seitt. 1971. Umschan 79:778-783

Müller G (1981) Die Schwermetallbelastung der sediments des Neckars und seiner Nebenflusse: eine Bestandsaufnahme. Chemiker-Zeitung 05:157-164 
Pérez-López R, Nieto JM, López-Cascajosa MJ, Díaz-Blanco MJ, Sarmiento AM, Oliveira V, Sánchez-Rodas D (2011) Evaluation of heavy metals and arsenic speciation discharged by the industrial activity on the Tinto-Odiel estuary, SW Spain. Mar Pollut Bull 62: 405-411

Peng X, Zhou H, Weng H, Pan J, Chen G (2003) Characteristics of major elements' constitutions and distributions in sediments of the Lingdingyang in the Pearl River Estuary and their geochemical implication. Journal of Zhejiang University (Science Edition)/Zhejiang Daxue Xuebao (Lixue Ban) 30, 697-702

Price N, Brand T, Pates JM, Mowbray S, Theocharis A, Civitarese G, Miserocchi S, Heussner S, Lindsay F (1999) Horizontal distributions of biogenic and lithogenic elements of suspended particulate matter in the Mediterranean Sea. Prog Oceanogr 44:191-218

Qi S, Leipe T, Rueckert P, Di Z, Harff J (2010) Geochemical sources, deposition and enrichment of heavy metals in short sediment cores from the Pearl River Estuary, Southern China. J Mar Syst 82:S28-S42

Qian J, Shan X-q, Wang Z-j, Tu Q (1996) Distribution and plant availability of heavy metals in different particle-size fractions of soil. Sci Total Environ 187:131-141

Raghunath R, Tripathi R, Kumar AV, Sathe A, Khandekar R, Nambi K (1999) Assessment of $\mathrm{Pb}, \mathrm{Cd}, \mathrm{Cu}$, and $\mathrm{Zn}$ exposures of 6-to 10-yearold children in Mumbai. Environ Res 80:215-221

Rubio B, Nombela M, Vilas F (2000) Geochemistry of major and trace elements in sediments of the Ria de Vigo (NW Spain): an assessment of metal pollution. Mar Pollut Bull 40:968-980

Rudnick R, Gao S (2003) Composition of the continental crust. Treatise on Geochemistry 3:1-64

San Miguel E, Bolí J, Garcí R (2004) Vertical distribution of Th-isotope ratios, $210 \mathrm{~Pb}, 226 \mathrm{Ra}$ and $137 \mathrm{Cs}$ in sediment cores from an estuary affected by anthropogenic releases. Sci Total Environ 318:143-157

Schropp SJ, Lewis FG, Windom HL, Ryan JD, Calder FD, Burney LC (1990) Interpretation of metal concentrations in estuarine sediments of Florida using aluminum as a reference element. Estuaries 13:227-235

Shi Y, Liang K, Xia Z (2006) Pollution of heavy metals in the Lingdingyang of Pearl river estuary and its assessment of potential ecological risk. Gresearch of Eological South China Sea, 52-59

Siddique A, Mumtaz M, Zaigham NA, Mallick KA, Saied S, Zahir E, Khwaja HA (2009) Heavy metal toxicity levels in the coastal sediments of the Arabian Sea along the urban Karachi (Pakistan) region. Mar Pollut Bull 58:1406-1414

Taylor S (1964) Abundance of chemical elements in the continental crust: a new table. Geochim Cosmochim Acta 28:1273-1285

Taylor SR, McLennan SM (1995) The geochemical evolution of the continental crust. Rev Geophys 33:241-265

Turekian KK, Wedepohl KH (1961) Distribution of the elements in some major units of the earth's crust. Geol Soc Am Bull 72:175-192

Varol M (2011) Assessment of heavy metal contamination in sediments of the Tigris River (Turkey) using pollution indices and multivariate statistical techniques. J Hazard Mater 195: 355-364

Venkatramanan S, Chung S-y, Ramkumar T, Gnanachandrasamy G, Kim TH (2015) Evaluation of geochemical behavior and heavy metal distribution of sediments: the case study of the Tirumalairajan river estuary, southeast coast of India. International Journal of Sediment Research 30:28-38

Wang F, Wang W-X, Huang X-P (2012) Spatial distribution of gut juice extractable $\mathrm{Cu}, \mathrm{Pb}$ and $\mathrm{Zn}$ in sediments from the Pearl River Estuary, Southern China. Mar Environ Res 77:112-119

Wang H, Wang J, Liu R, Yu W, Shen Z (2015) Spatial variation, environmental risk and biological hazard assessment of heavy metals in surface sediments of the Yangtze River estuary. Mar Pollut Bull 93: $250-258$
Wang J, Huang C, Ni Z, Jin G, Cao L, Chen H, Waxi L (2014a) Analysis on distribution, speciation and source of heavy metals in superficial sediments in the Pearl River Estuary. Mar Sci Bull 33:259-267

Wang J, Liu R, Zhang P, Yu W, Shen Z, Feng C (2014b) Spatial variation, environmental assessment and source identification of heavy metals in sediments of the Yangtze River Estuary. Mar Pollut Bull 87:364-373

Woods AM, Lloyd JM, Zong Y, Brodie CR (2012) Spatial mapping of Pearl River Estuary surface sediment geochemistry: influence of data analysis on environmental interpretation. Estuar Coast Shelf Sci 115:218-233

Xia N, Zhang Q, Yao D, Li G (2008) Geochemical analysis of marine sediments using fused glass disc by X-ray fluorescence spectrometry. Chin J Oceanol Limnol 26:475-479

Xia P, Meng X, Yin P, Cao Z, Wang X (2011) Eighty-year sedimentary record of heavy metal inputs in the intertidal sediments from the Nanliu River estuary, Beibu Gulf of South China Sea. Environ Pollut 159:92-99

Xia Z (2005) Characters of underwater topography and geomorphology in inner Lingdingyang firth of the Pearl River (Zhuanghai River) estuary. Marine Geology and Quaternary Geology 25:20-24

Xu G, Liu J, Pei S, Gao M, Hu G, Kong X (2015a) Sediment properties and trace metal pollution assessment in surface sediments of the Laizhou Bay, China. Environ Sci Pollut Res 22:11634-11647

Xu G, Liu J, Pei S, Hu G, Kong X (2015b) Geochemical background and ecological risk of heavy metals in surface sediments from the west Zhoushan Fishing Ground of East China Sea. Environ Sci Pollut Res 22:20283-20294

Xu G, Pei S, Liu J, Gao M, Hu G, Kong X (2015c) Surface sediment properties and heavy metal pollution assessment in the near-shore area, north Shandong Peninsula. Mar Pollut Bull 95:395-401

Xu Y, Sun Q, Yi L, Yin X, Wang A, Li Y, Chen J (2014) The source of natural and anthropogenic heavy metals in the sediments of the Minjiang River Estuary (SE China): implications for historical pollution. Sci Total Environ 493:729-736

Yang X, Yuan X, Zhang A, Mao Y, Li Q, Zong H, Wang L, Li X (2015) Spatial distribution and sources of heavy metals and petroleum hydrocarbon in the sand flats of Shuangtaizi Estuary, Bohai Sea of China. Mar Pollut Bull 95:503-512

Yang Y, Chen F, Zhang L, Liu J, Wu S, Kang M (2012) Comprehensive assessment of heavy metal contamination in sediment of the Pearl River Estuary and adjacent shelf. Mar Pollut Bull 64:1947-1955

Ye F, Huang X, Zhang D, Tian L, Zeng Y (2012) Distribution of heavy metals in sediments of the Pearl River Estuary, Southern China: implications for sources and historical changes. J Environ Sci 24: 579-588

Yu RL, Yuan X, Zhao YH, Hu GR, Tu XL (2008) Heavy metal pollution in intertidal sediments from Quanzhou Bay, China. J Environ Sci 20: 664-669

Yu X, Yan Y, Wang W-X (2010) The distribution and speciation of trace metals in surface sediments from the Pearl River Estuary and the Daya Bay, Southern China. Mar Pollut Bull 60:1364-1371

Zhang J, Liu C (2002) Riverine composition and estuarine geochemistry of particulate metals in China - weathering features, anthropogenic impact and chemical fluxes. Estuar Coast Shelf Sci 54:1051-1070

Zhang L, Shi Z, Jiang Z, Zhang J, Wang F, Huang X (2015a) Distribution and bioaccumulation of heavy metals in marine organisms in east and west Guangdong coastal regions, South China. Mar Pollut Bull

Zhang L, Shi Z, Zhang J, Jiang Z, Wang F, Huang X (2015b) Spatial and seasonal characteristics of dissolved heavy metals in the east and west Guangdong coastal waters, South China. Mar Pollut Bull

Zhang SR, Lu XX, Higgitt DL, Chen CTA, Sun HG, Han JT (2007) Water chemistry of the Zhujiang (Pearl River): natural processes and anthropogenic influences. J Geophys Res: Earth Surf 112 
Zhang W, Feng H, Chang J, Qu J, Xie H, Yu L (2009a) Heavy metal contamination in surface sediments of Yangtze River intertidal zone: an assessment from different indexes. Environ Pollut 157:1533-1543

Zhang W, Jin H, Zhang F, Zhao G, Yang K, Li H, Bai Y, Gao W (2009b) Organic carbon distribution in the Yangtze River estuary-Hangzhou Bay and its adjacent sea area. Advances in Earth Science 24:1202-1209

Zhang YH, Du JM (2005) Background values of pollutants in sediments of the South China Sea. Acta Oceanol Sin 27:161-166
Zhou G, Sun B, Zeng D, Wei H, Liu Z, Zhang B (2014) Vertical distribution of trace elements in the sediment cores from major rivers in East China and its implication on geochemical background and anthropogenic effects. J Geochem Explor 139:53-67

Zhou H-y, Peng X-t, Pan J-m (2004) Distribution, source and enrichment of some chemical elements in sediments of the Pearl River Estuary, China. Cont Shelf Res 24:1857-1875

Zhu L, Xu J, Wang F, Lee B (2011): An assessment of selected heavy metal contamination in the surface sediments from the South China Sea before 1998. Journal of Geochemical Exploration 108:1-14 